stellar medium) can then only be explained if most of the high-energy electrons responsible for the emission originate within the supernova, as proposed by van der Laan for the early stages of the expansion.

There appear to be a total of some 10-12 localized regions distributed around the shell which have an even greater volume emissivity; these sources, which have typical dimensions of $0 \cdot 2-0.3$ parsec, might be associated with regions of greater magnetic field strength.
We thank the Director of the University Mathematical Laboratory for the use of Edsac II.

1 Ryle, M., Nature, 194, 517 (1962).

2 Lequeux, J., Ann. d'Astrophys, 25, 221 (1962).

${ }^{3}$ Maltby, P., and Moffet, A. T., Astrophys. J., Supp., 7, 141 (1962).

- Moffet, A. T., Science, 146, 764 (1964).

- Ryle, M., and Neville, A. C., Mon. Not. Roy. Astro. Soc., 125, 39 (1962).

6 Minkowski, R., IAU/URSI Symp. Radio Astronomy, Paris, 315 (1958).

7 Laan, H. van der, Mon. Not. Roy. Astro. Soc., 124, 125 (1962).

${ }^{8}$ Laan, H. van der, Mon. Not. Roy. Astro. Soc., 124, 179 (1962).

\title{
OBITUARIES
}

\section{Prof. J. M. F. Drummond}

WrTH the death of James Montagu Frank Drummond, emeritus professor of botany in the University of Manchester, at his home in Exmouth at the age of eighty-three, British botany has lost an unusually well informed academic and practical exponent. He was born in 1881, the second son of J. R. Drummond of the Indian Civil Service. $\mathrm{He}$ is survived by his second wife, née Dorothy Maria Farrant. His first wife, née Agnes Marguerite Ives, died in 1923.

Drummond was educated at King's College, London, and at Gonville and Caius, Cambridge, where he had the distinction of holding the Frank Smart research studentship during 1904-6. His first appointment as lecturer in botany at Armstrong College, Newcastle upon Tyne (1906), was followed, in 1909 , by his joining the staff of Prof. F. O. Bower in the University of Glasgow as lecturer in plant physiology. There he remained until 1921, his teaching on various branches of botany being much appreciated by his students. It was during this period that he produced his masterly translation and up-to-date annotation of an eminent - and extensive-German text, Dr. G. Haberlandt's Physiologische Pflanzenanatomie (Physiological Plant Anatomy), 1914. His academic work was interrupted by the First World War when he saw active service with the Highland Light Infantry in France and the Palestine campaign.

When, in 1921, the Scottish Plant Breeding Station was established at Corstorphine, Midlothian, Drummond was invited to become its first director. His botanical interests, always broadly based and liberal, now turned in the direction of geneties, with special emphasis on the improvement of cultivated plants. Under his care the new Station was staffed and organized and was soon known for its varied and progressive activities. His work in this new field is recorded in the annual reports of the Station and in various public addresses. But still further opportunities were to eome his way. In 1925, he was appointed Regius professor of botany in the University of Glasgow, and in 1930 he became George Harrison professor of botany in the University of Manchester, a post which he held until his retirement in 1946. During this period the trustees of the former Manchester Royal Botanical Society made a considerable bequest to the University to promote interest in horticulture in the region. On the funds thus made available, Prof. Drummond purchased and developed in Cheshire what are now the Jodrell Bank Botanical Experimental Grounds, and he also established a University lectureship in horticulture and a system of training for student gardeners. All this was very close to his heart: he was a true lover of plants and gardens and possessed an unrivalled knowledge of species, both native and exotic.

Much of the effect of Prof. Drummond's work lay, not so much in what he achieved under his own name, but rather in what he did for others and enabled them to achieve. For example, he greatly assisted Prof. Bower in re-editing, and in incorporating new material in, the third edition of Botany of the Living Plant. To all, but especially to his younger colleagues and students, he was unstinting of his help and encouragement of their work. His outlook, thinking and writing were of unusual clarity and perspicacity. He held firmly to the view that a university was not simply a seat of learning but essentially a place both for study and character formation. This led him, among many other activities, to continue his interest in military training, and from 1932 until 1945 he was officer-incommand of the University Officers' (Senior) Training Corps. During the Second World War this greatly enlarged unit, which he organized and commanded with distinction, functioned as the 61st (Lancs.) Battalion of the Home Guard.

C. W. WARDLAW

\section{Mrs. Dorothea Waley Singer}

Mrs. Dorothea Singer, the widow of Prof. Charles Singer, the historian of medicine and science, died on June 24, 1964. She was well known in many countries, especially for her work on early manuscripts dealing with science and medicine, and for her activities on various international bodies.

Dorothea Waley Singer, the eldest daughter of Nathaniel L. Cohen, and of Julia M. Waley, was born in London on December 17,1882 . In early womanhood she spent some years at Queen's College, London, and in 1910 she married Charles Singer, who was then engaged mainly in clinical and pathological work. Soon afterwards they both became interested in the history of medicine and science, and in 1913 they presented a joint communication on the history of the contagium vivum at the International Medical Congress held in London in that year. In following years they wrote several joint papers, dealing mainly with. medieval medicine.

Meanwhile, Mrs. Singer had been very actively engaged on studying the surviving medieval manuscripts in the British Isles which dealt with different aspects of science and medicine. In 1916 she presented before the History Section of the Royal Society of Medicine a very careful and detailed study of more than a hundred plague tractates of the fourteenth and fifteenth centuries. She had for some years been trying to catalogue and codify the manuscripts in Britain which bore in any way on science and medicine, and by 1919 she knew of more than 30,000 , many of which were, of course, direct copies or variants. The full fruition of these investigations began to be seen in 1924, when the Union Académique International published the first volume of her monumental catalogue of alchemical manuseripts in the British Isles. The first volume is a small work because it deals only with the comparatively few Greek manuscripts in Britain. But the three succeeding volumes (1928-31) deal with the vast number of Latin and vernacular manuscripts, and they form a catalogue of great complexity and scholarship which will remain a standard work.

Mrs. Singer had continued to work on plague tractates, and in 1950 she published a definitive catalogue of Latin and vernacular works on plague which dated from before the sixteenth century and were extant in Great Britain. Her cumulative catalogue, dealing with all scientific subjects, forms a very large collection of cards, and microfilms of it are deposited in some of the great libraries of the world. 